\title{
Diachronic Study on the Derivation of There in There-be Construction
}

\author{
Qun Ren \\ Foreign Language Department, Huaiyin Normal University, Huaian, Jiangsu, China
}

\begin{abstract}
In the circle of linguistics, numerous attempts have been made to explore there-be construction in the fields of syntax, semantics, and pragmatics, but there is little touching on the derivation of the word there. In consequence, herein the focus and effort are put on the issues of there, especially the derivation of there. It begins with the exploration of historical sources touching upon there and all the analyses are based on the historical study on there constructions. In the historical study, it is demonstrated that there-be construction derivates from archaic Then $-\mathrm{V}$ pattern and PP-V pattern by analogy when the subject is obligatory in the clause.
\end{abstract}

Index Terms - there-be construction, derivation of there, diachronic study

\section{Theoretical AND Methodological Basis}

\section{A. Synchronic and Diachronic Study}

To delimit and define the boundaries of language study, Saussure first distinguishes between historical linguistics and descriptive linguistics, or diachronic and synchronic analyses respectively. The description of a language at some point in time is a synchronic study; the description of a language as it changes through time is a diachronic study, or a historical study, studying the historical development of language over a period of time. On the one hand, the synchronic study of linguistic systems can provide insights that can be used in reconstructing their past. On the other hand, synchronic linguistic systems are in some respects unsystematic: the numerous irregular relics of earlier systems (the exceptions to the rule), which are simply inexplicable in synchronic terms, can only be explained by reference to past states and developments. The unstable state of a language at any given point of time is the consequence of historical processes. (Schendl, 2003, p.8)

In this light, there are generally two approaches to the study of linguistics, namely synchronic and diachronic. If the signs of language had no changes, the distinction between Synchronic analyses and Diachronic analyses is meaningless. But a language is evolving continually, so linguistics has both the current structural properties of language and historical dimensions to be studied.

It has been learned that generative linguists think there appears by inserting or by moving and merging, but they do not offer why, which still causes puzzles. Others like Lyons assert existential there comes from an adverbial. They similarly do not make a detailed and convincing statement and argument. Therefore, it is crucial and necessary to consider the derivation in the first place. Certainly, the focus of discussion herein is the derivation of there. As it is mentioned above, there are some linguists like Lyons having related the derivation of there, but few successors have gone deep into it. As a result, the diachronic study of the construction is required and needed.

\section{B. Historical Mechanisms}

In the history of human language there are a variety of mechanisms of language change, more important of which are analogy, the reanalysis of surface structures and the process of grammaticalization.

1. Analogy

In linguistics, analogy is a most important phenomenon, which can be illustrated in the following form:

$\mathrm{A}: \mathrm{B}=\mathrm{C}: \mathrm{X}$

sow : sows $=$ cow $: X$

$\mathrm{X}=$ cows

An analogy can be the linguistic process that reduces word forms perceived as irregular by remaking them in the shape of more common forms that are governed by rules.

2. Reanalysis

Syntactic constructions may be or become ambiguous in specific contexts and speakers may come to favour a new analysis rather than the old one in the course of time. In general the two analyses will coexist for some time, till the new one may finally replace the old one and may subsequently even be extended to similar constructions. The reanalysis of a given surface structure is a major mechanism behind syntactic change.

Consider the following literal translation and syntactic analysis for an OE sentence:

To-the-king pleased (the) pears. 
$\mathrm{O}$ (dat. Sing.)- V(past plur.)- S(nom. plur.)

The extensive loss of inflections in ME resulted in the uninflected form the king, which was formally identical for both subject and object. Owing to the loss of the verbal plural marking by the late ME period, verb forms such as liked equally had become unmarked for number and person. The resulting construction The king liked pears now allows for two different syntactic analyses, since each of the two nouns may be interpreted as grammatical subject or object, i.e. the king (s/o?) kiked (sing/plur?) (the) pears (s/o?), with the overall interpretations in spite of a slight semantic change of the verb, cf. The king liked the pears vs. The pears pleased (to) the king. The predominating unmarked word order SVB led to the reanalysis of the king as subject, though the old analysis of the king as object was still supported by the personal pronouns (he vs. him) and survived with some verbs into the $16^{\text {th }} \mathrm{c}$.

3. Grammaticalization

In the nineteenth century the study of the development of grammatical forms was motivated by the general interest in the etymological roots of languages. The aim of grammaticalization is to show "where a lexical unit ... assumes a grammatical function, or where a grammatical unit assumes a more grammatical function" (Heine, 1991, p.2) Consider the development of the expression "I think", as investigated by Thompson and Mulac (1991, p.315)

[1] I think that we are definitely moving towards being more technological.

[2] I think exercise is really beneficial to anybody.

[3] It's just your point of view ... what you like to do in your spare time I think.

Sentence [1] consists of the main clause I think and a subordinate clause introduced by that. Sentence [2] may be analyzed as the syntactic construction with the subordinator that omitted. Yet this explanation does not apply for [3], where I think has the final position, which suggests that $I$ think functions as a kind of additional commentary. Once this interpretation has been established for [3], there is no reason why it should not be extended to [2] as well. As a result, both [2] and [3] are thought to be the construction consisting of a main clause plus the adverbial phrase I think either at the beginning or at the end. The phrase $I$ think is turned into an adverbial, in which a grammaticalization process reverses the weight of the sentence constituents. If the driving force behind this is identified, it is found that the change is most probably motivated by the requirements of discourse.

\section{Derivation OF THERE IN THERE-BE CONSTRUCTION}

\section{A. Diachronic Study}

Naturally, the diachronic study of a linguistic phenomenon requires substantial linguistic primary sources. Here list related primary texts from Freeborn's From Old English to Standard English. Of course, they start from the so-called Old English(OE), which are mostly from the Anglo-Saxon Chronicle, which has survived in several manuscripts, known as the Peterborough Chronicle and the Parker Chronicle.

Other sources are the prose, in The Cambridge History of the English Language (vol. I: the beginnings to 1066), selected from the Alfredian era (late 9th c) and of AElfric (early 11th c): amongst the important texts of the Alfredian era are the Anglo-Saxon Chronicles(or, rather, the Parker Chronicle), the translation of the Cura pastoralis, Alfred's translation of Boethius, and although not directly attributable to Alfred, the translations of Orosius' Historia adversum paganos and Bede's Historia ecclesiastica.

In the following listing, to be brief, the abbreviations are used as: WW for the word-for-word translations; MnE for paraphrases in Modern English; OE for Old English; ME for Middle English; Cambridge for the book The Cambridge History of the English Language vol. I; OE-SE for the book From Old English to Standard English. As to the signs, " $>$ " stands for "develop into"; " $<>$ " is the one in which there are writing letters, while "[ ]"phonetic sounds; "*" indicates the sentence is not generally acceptable.

Variants of there: The OE word for there is par and in early middle English about the 12th century $\langle\mathrm{a}\rangle$ replaced $\langle æ>$, namely, par, with a variant per in some dialects. Then the word begins to take the beginning <th->, but is not completed there even at the beginning of the 15th c. (Hogg,2002, p.153) Thus, there is inconsistency within a dialectal area, and even within the same manuscript sometimes. It is difficult to know whether some of the differences are simply variations in the spelling or in the form and pronunciation of a word. (ibid, p.165)

Consider the following texts with there:

[4] Peterborough Chronicle for AD 878 (It is a typical entry in the Anglo-Saxon Chronicle describing the ravages of the Danish armies during king Alfred's reign.) (OE - SE)

WW: \& after at easter built alfred king with-little company fortress at Athelney \& from that fortress was fighting against the host. \& of-somerset the part that there (bær) nearest was (wæs). then in the seventh week after easter he rode to egbertstone by east of-selwood \& to-him came there (pær) back of-somerset-men all. \& wiltshire \& hampshire the part that of-it on-this-side-of sea was. \& of-him glad they-were.\& he went after on night from those camps to iley. \& later after one night to edington. \& there (pær) fought against all the host \& it put-to-fight. \& it after rode up-to the fortress. \& there (pær) sat 14 nights. \& then gave the host him hostages and great oaths.

[5] (The entry recording the battle of Brunanburh in the Parker Chronicle is a graphic poetical account of the battle.) (ibid)

WW: there (pær) lay man many-a. by-spears killed. man Northern. over shield shot. also Scots too. weary of-battle sated. 
[6] OE Gospels (Matthew 28: 8-19): no time stated, may be in the 1000s, following Wulfstan, Archbishop of York from 1003 to 1023 (ibid)

WW: Then went they hurriedly from the tomb with fear and with much joy, and ran and told it to-his disciples. And behold then came the Lord against them and said, "Well be you." They approached and took his feet and to him worshipped. Then said the Lord to them, "(Do) not fear ye you. Go and tell my brethren that they go into Galilee. There (pær) they will see me." When they went then came some of the watchmen into the city and said to the of-priests elders all the things that there (ðær) happened were. Then gathered the elders them and held meeting and gave to-the soldiers much money, and said, "Say that his disciples came by night and stole him when we slept. And if the judge this asks, we will advise him and make you secure." Then took they the money, and did all as they instructed were, and this story was spread abroad among (the) Jews to this present day. Then went the eleven disciples to the mountain where (pær) the Lord them (had) appointed. And him there (bær) saw and they (to) him worshipped.

[7] Part of the Peterborough chronicle for 1066 (ibid)

WW: ... \& harold earl succeeded to england's kingdom. as the king it to-him granted... He went out with ship-force against William. \& meanwhile came tosting earl into humber with 60 ships...\& the shipmen him forsook...\& him met Harold the Norwegian king with 300 ships. And tostig him to submitted. \& they both went into humber until they came to york. \& them against fought morcar earl. \& edwin earl. \& the norwegian king all victory gained. \& one told harold king how it was there (pær) done $\&$ happened. \& he came with great army of-english men, \& met him at stamford bridge. \& slew. \& the earl tostig. \& all the host manfully ovecame \& meanwhile came william earl up at hastings on st michael's mass day. \& harold came from-north \& him against fought before his army came all. \& there (pær) he fell. \& his two brothers Gurth \& leofwine. and William this land conquered. \& came to westminster.

[8] Cambridge:

WW: ... and there (ðær) dangerously wounded was, and even slain would-have-been, if his son him not had-helped (Or 4 8.186.22)

MnE: ... and was dangerously wounded there, and would even have been killed, had his son not helped him.

WW: ... but they not dared there (pær) in come (Or 1 1.17.27)

MnE: ... but they did not dare enter there.

So far, it has been shown that Old English is basically verb-final, or OV in most respects, which by no means excludes the cases that occasionally the finite verb may precede the object, but the sequence OV is the so-called unmarked order; a deviation from this basic arrangement serves to achieve some special purposes (e.g. to avoid the ambiguity between the nominal subjects and objects); the surface category subject is clearly not obligatory in OE. However, there is wide application of what is often called verb-second (V2) order in most OE main clauses. By V2 order it means the placement of finite verbs following an initial constituent, typically an adverb, like $p a$ (then), paer (there), na (not at all), ne (not), etc.. Throughout the OE period, then, there is a gradual shift from greater to lesser use of verb-final patterns. (Hogg, 2002, p.275, p.276)

Then par (there), according to the word order and the role of light and heavy element is mostly put before the predicate verb, typically after the conjunction and, and used to be anaphoric reference to the preceding adverbial place. It also functions in the discourse as linking up the clauses.

On the other hand, par (there) in some other cases functioned as relative, conditional, and temporal. For example, if there is an NP or adverb head with locative adverbial function, an invariant adverbial relative par meaning where, in which, to which, occasionally from which may be used.

[9] Cambridge:

WW: One was Babylonia, where (pær) Ninus ruled $\quad$ (Or 2 1.58.28)

WW: that are India's boundaries there (pær) where (pær) Caucasus that mountain is in the-north (Or 1 1.10.15)

MnE: Those are India's boundaries in the north of which is the mountain Caucasus.

WW: then went that bishop into that other church where (pær) that martyr inside lay, and asked that churchwarden where (hwær) of-that holy-man weapons were. (AECHom I, 30 452.1)

MnE: Then the bishop went into the other church in which the martyr lay, and asked the warden where the holy man's weapons were.

For another, there (bar) plus the subjunctive in both clauses is an alternative for the imaginary or unreal condition.

[10] Cambridge:

WW: There (pær) we our selves had-judged, then not would-have-judged us not god

MnE: If we judged ourselves, then God would not judge us. $\quad$ (CP 53 415.7)

Strong evidence that paer did indeed have a conditional meaning comes from the fact that if and paer are sometimes found in parallel conditional constructions. Furthermore, they can be found alternating in different manuscripts of the same work. (Hogg, 2002, p.257-258)

There's also evidence for par occurring with a temporal sense (in the sense of both 'at that time' and 'whenever').

[11] Cambridge:

WW: ... but mutter with jaws there (pær) they should speak-aloud (WHom 16b 13)

MnE:... but mutter with their jaws when they should speak aloud.

WW: and forbade that one never there (ðær) after not built (Or 6 7.262.21) 
MnE: And forbade anyone to build there after.

It can be concluded from the above examples that in OE paer (there) is an adverb, mostly referring to a previously mentioned location in reality. Sometimes, it is abstracted by referring to the condition (e.g. [10]) or time (e.g. [11]). Another example in the following shows evidence that there is gradually becoming abstract.

[12] This short extract is the opening of an Old English homily, copied second half of 12th century. (OE-SE)

WW: ... He who me serves, follow he me then; and there (pær) where (ðær) I myself am, there (per) is (bið) also my servant; ...

Here par (there) is not any location mentioned in the preceding clause, but any place, which is not definite or specific though it can still be a place in reality. Here there (per) is (bið) is inversion though in form it is similar to there-be construction. Other texts show current typical there-be construction has not appeared.

[13] Cambridge:

WW: Then is one port in south-of that land, which one calls Skiringssalt (Or 1 1.19.10)

MnE: Then there is a port in the south of that country which is called Skiringssalt.

WW: and in each fortress is king... (Or 1 1.20.14)

$\mathrm{MnE}$ : and in each fortress there is a king ...

WW: In this abbess's minster was (wæe)a bother specially ... honoured

MnE: In this abbess's minster there was a certain brother who was especially ... honoured (Bede 4 25.342.3)

WW: ... therefore not-is no doubt that he forgiveness give not-will to-them PT it earn want

MnE: ... therefore there is no doubt that he will give forgiveness to those who want to earn it. (HomS 17 (BlHom 5) 178)

WW: In those days were (wæron) in Isle-of-Wight three women, those two were blind through nine years' time

MnE: In those days there were three women in the Isle of Wight, two of them had been blind for nine years. (AELS (Swithun) 156)

In most cases, as [13] shows, where there is anticipatory such as then, prepositional phrases in each fortress, In this abbess's minster, In those days, or connecting adverb therefore, there or it is not needed in the OE. Here are more:

[14] Cambridge:

WW: thus then is to-me now very difficult for me to excite their spirit.

MnE: Thus then it is very difficult for me to excite their spirit. (Or 4 13.212.30)

WW: then was great doubt ... (AECHom I, 34,506.17)

MnE: then there was considerable doubt ...

Despite most evidence for the absence of par (there) in the clauses, there is still a first glimmer of the dawn as the following shows. Exactly speaking, it is a rudiment of there-be construction.

[15] Cambridge:

WW: That Estland is (is) very big, and there (pær) is (bið) very many fortresses, and in each fortress is (bið) king. And there (pær) is (bið) very much honey ... There (bær) is (bið) very much fighting among them. And not is (bið) there (ðær) any ale brewed among Ests, but there (pær) is (bið) mead enough. And there (pær) is (is) among Ests custom, when there (pær) is (bið) man dead, that he lies inside unburned among his kin and friends month ... And all that time pe ${ }^{\mathbb{1}}$ that body is (bið) inside, there (pær) shall be (beon) drink and play. (Or 11.2014 )

$\mathrm{MnE}$ : The land of the Ests is very large, and there are very many fortresses there, and in each fortress there is a king. And there is very much honey ... there is very much conflict between them. And there is no ale brewed among the Ests, but there is enough mead. And there is a custom among the Ests that, when there is a man dead, he lies inside uncremated among his kinsmen and friends for a month ... And all the time that the body is inside, there (pær) shall be drink and play.

The Cambridge History considers, of the eight instances of par in the above text from Wulfstan's description of Estonia in Orosius, "the first two seem to be clearly locative and substitutable" by on Estlande, and the last six are at least potentially empty subject-position holders". "The analysis of the last (pær) as an empty subject-marker rather than a true adverb rests on the assumption that it is unlikely to be anaphoric to inside - since drinking and playing were probably not restricted to the very same location in which the body lay at rest." (Cambridge: 218, 235)

However, herein is a little difference, in fact. The last six paers, especially the ones after and, can substitute for on Estlande, too, because par is favored to be adaptor connecting clauses in the context, with the exception of "ne bið ðær (not is there)" when ne takes the initiative. The last two paers in [4] are a testimony to it. More evidence is as follows:

[16] Cambridge:

WW: he fought against Goths and put-to-flight was and driven into one fortress and there (pær) was (wearð) in one house burned-to-death. There (pær) was (wæs) very right sentence carried out. (Or 6 34.290.32)

MnE: He fought against the Goths and was put to flight and driven into a fortress; and he was burned to death in a house. Very just judgement was carried out there ...

WW: they dug each part of-that vegetable-garden of-that PT there (pær) before not-dug was (GD 202.3)

MnE: They dug every part of the vegetable garden that had been left undug before.

\footnotetext{
(1) Note: There was a widely used subordinating particle $p e$; since it has no exact equivalent in PDE, and its structural properties are not fully agreed on, it is glossed here simply as PT (short for particle). (Cambridge: 171)
} 
In [16] the three thers refer to in the fortress and in the vegetable garden, in the corresponding MnE version all can be omitted. What's more evident is that the clauses are bound up with ther (there) in the form of an initial word, which is the main function of there in $\mathrm{OE}$ accompanying anaphoric reference. This also is the result of OE word order, e.g. the ending clauses in [16].

In historical linguistic view, such a linguistic phenomenon exists because a grammatical subject is not obligatory in OE. For another, as the above shows, basic patterns in OE are overridden by other phenomena. While the basic OV word order of $\mathrm{OE}$ is most easily observed in subordinate clauses, in main clauses, it is overridden by the verb-second order, i.e. AV order, in most main clauses, such as in [13] and [15], finite verbs following an initial constituent, typically an adverb: a pronominal adverb of locative, temporal or negative origin.

A second phenomenon is the fact that light, i.e. phonologically short, often adverbial or pronominal forms, are preferred clause-initially, and heavy elements, typically complex phrases or subordinate clauses, are preferred sentence-finally. Such preference continues down to the present day, which is the so-called end-weight principle for light elements clause-initially and heavy elements in clause-final position.

From a discourse perspective, differences in word order can, Hopper suggests, be exploited to give pragmatic cues to reference. In MnE nominals are expected to do the work of distinguishing reference, while in OE, in Hopper's opinion, construction Then-Verb signals a change of subject. (Cambridge: 278) In fact, other adverb-initial constructions also have such a function, such as preposition phrases in [13], per in [12], ond parr(and there) in [15].

As it has been mentioned above, the subject is not obligatory till in ME. Nevertheless, there is some evidence that in OE there is a tendency to fill the subject position by the use of hit (it) in impersonal construction and the use of par in certain copula constructions with an indefinite subject. "Unlike hit in impersonals, paer occurs with a subject. Its function is not to fill a totally empty subject position, but rather to place a definite element in subject position, where otherwise an indefinite would occur, and thus to correlate subject position with definiteness, at least in copula constructions. In MnE this correlation is obligatory in existential sentences with indefinite subjects, cf. There's a problem with this analysis vs.* A problem is with this analysis. In OE it is optional." (ibid: 216-218) This option has been demonstrated by both the non-use and the use of paer in the beginning sentences of [15].

In Cambridge History of the English Language, it says, although par-constructions are found in Beowulf, they are very rare until later OE, especially AElfric. Then there-be construction is becoming common and well-established.

[17] La3amon's Brut (a chronicle history of Britain written towards the end of the 12th century by a priest in a West Milands dialect) (OE-SE) ${ }^{2}$

EME: AN preost wes on leoden : La3amon wes ihoten...vppen seuarne stape: sel par him puhte... boc he nom pe pridde: leide per amidden...

WW: (There) was a priest in (the) land, La3amon (who) was named ...upon Severn's bank - good there (to) him (it) seemed... (a) book he took the third, laid there in (the) midst...

[18] Introduction to the life of St Kenelm (early middle English - 13th c) (OE - SE) (preceding lines)

Vif kinges pere were pulke tyme. In Engelond ido...

Fram pe est into pe west. and also pere inne beop

Manie wateres god inou. as 3e alday iseo

Ac preo wateres principals. Per beop of alle iwis

Homber and Temese. Seuerne pe pridde is.

Translation: There were five kings in England at that time...

From east to west, and therein also are

Many good rivers, as you can see any day,

But there are three principal rivers of all,

Humber and Thames, and Severn is the third.

This is a better example showing the embryonic period of there-be construction: the NP, still the attention, is initial.

[19] The Bestiary - The Whale (written in the East Midland dialect in the second half of the $13^{\text {th }}$ century) (OE - SE)

WW: Whale is a fish the biggest that in water is this fish lives on the sea bottom and lives there ever healthy and sound

[20] The Owl and the Nightingale (The poem can be fairly accurately dated to the 1190s. The original has not survived, but the facsimile was probably copied after the mid-13th century.) (OE - SE)

Edited version: pe niz tingale bigon pe speche

In one hurne of one breche,

An sat up one vairebo3

par were (pere) abute blosme ino3e

Literal translation: The nightingale began the speech In a corner of a clearing

And sat upon a fair bough

Around which were blossoms enough

\footnotetext{
(2) Note: Freeborn regards English in this period as Early Middle English.
} 
[21] Robert of Gloucester's Chronicle, about c.1300 (late in 13th c - 1272) (ibid)

a. WW: ... I believe there (per) ne are (bep) in all the world countries none that ne-hold to their own speech but England alone. ... Aldred was his name. There (per) ne-was (nas) prince in all the world of so noble fame.

b. WW: A few drops of rain there (per) fell great enough...gentlemen that were taken at Evesham many a one like Sir Guy... Sir Baldwin...\& Sir Robert who...these \& many more were taken \& the same murdered there (pere) but the Welsh footmen that there (per) were many a one at the beginning of the battle began to flee each one \& came through Tewkesbury \& there (pere) men of the town slew them all to the ground so that there (pere) they lay down

[22] Kentish dialect - Michael of Northgate's Ayenbyte of Inwyt, 1340 (ibid)

Efterward Per wes a poure man, ase me zayp, pet hedde ane cow...

WW: afterward there was a poor man, as I am told, that had a cow...

[23] A later 14th-century South West dialect of ME (ibid)

John of Trevisa on the English language in 1385

WW: As it is known how many kinds (of) people are in this island there(ber) are(bup) also of so many people languages and tongues.

$\langle$ th $\rangle$ - has not replaced $\langle\mathrm{p}\rangle$ in Trevisa, letter $\langle\mathrm{p}\rangle$ survived into the 15 th $\mathrm{c}$.

[24] The 14th-century Scots English dialect

John Barbour's The Bruce (ibid)

WW: ... And Sir Walter the good Stewart

With armed men had to ride about

And see where that there (yar) was (war) most doubt

And bring help there (yar) with his company. ...

[25] Here are facsimiles, from the Hengwrt MS, of an extract from the Prologue to Chaucer's Friar Tale in the late $14^{\text {th }}$ century. (ibid)

Hengwrt MS: Whilom/ ther was duellynge in my contree An Erchedekne/ a man of hy degree That boldly/ dide execuciou(n)...

[26] 15th c London English - William caxton

In 1482 William Caxton printed a revised text of Trevisa's 1385 translation as in [23]. This provides an excellent example of some of the changes which had taken place in the language within a hundred years.

Caxton's version, 1482 (ibid)

As it is known how many maner peple ben in this Ilond ther ben also many langages and tonges.

[27] Caxton's the History of Reynart the Foxe, 1489 version

... whan the kynge of alle beestys had assemblyd alle hys court/ Ther was none of them alle ...

[28] The Celys were wool merchants, or staplers. They bought woolen fleeces in England and sold them on the Continent in Calais and Bruges.

George Cely in Calais to Richard Cely in London, 12 March 1478 (ibid)

MnE spelling and punctuation:

... and I was welcome unto my friends, for till my brother came to Calais there was (ther whas) none other tidings there (ther) but I was dead etc. pleaseth it you to understand there is (ther ys) now none merchants at Calais nor was but few this month, ...

[29] Note of events (June 1483) and memoranda by George Cely (ibid)

There is (ther ys) great romber (rumor) in the realm.

[30] Early Modern English - the 16th c. (ibid)

With vs ther was a doctour of phisik

In al this world ne was ther noon hym lik ...(318)

[31] in 1531: (ibid)

There can be nothing more conuenient than by litle ...

As the examples illustrate, in EME there in the inchoate there-be construction still can be regarded as the substitute for the former places, such as upon the bough in [20], in this island in [23]. What makes it fuzzier is there follows the indefinite noun at the beginning, and another is used in the relative clause after the definite noun in [21b]. Then later on, there are more and more typical established there-be constructions, most of which there coexists with the adverbial place. It is all the same reasonable if there in these clauses is analyzed as having the same reference as the place, especially when the place is in the preceding position, as in [30]. As Freeborn $(2000,318)$ says, "the filling of the subject slot in a clause with the dummy there or it had been established well before the beginning of the century, the 16th c., e.g. in Chaucer". At the same time, there has completed the process of abstraction, as the following shows:

[32] John Hart's An Orthographie, 1569

But in the moderne \& present manner of writing there is such confusion and disorder...

Here there is abstract space, in the manner of writing.

To sum up, in OE, par (there) is a locative adverb with anaphoric reference to the preceding adverbial place. On the other hand, par (there) in some other cases functioned as relative, conditional, and temporal. According to the word order and the role of light and heavy element, it is mostly put before the predicate verb, typically after the conjunction 
and, naturally functioning in the discourse as linking up the clauses. The current there-be construction has not appeared in $\mathrm{OE}$ and the pattern there (per) is (bið) is inversion though in form it is similar to there-be construction. Moreover, where there is anticipatory such as then, prepositional phrases or connecting adverbs signaling a change of subject, there is not needed in OE. ME shows the embryonic and growing period of there-be construction when the subject is obligatory, although the NP sometimes is still initial. At the same time there is gradually becoming abstract. Although there is the subject, the verb number is mostly in agreement with that of the NP. EMnE sees the maturity of there-be construction, where it is well-established.

\section{B. Historical Analysis}

Throughout the OE period, it can be seen that there is a gradual shift from greater to lesser use of verb-final patterns. Some researchers, such as Strang (1970), argue that the word order change was primarily motivated by the increased role in the middle period of light versus heavy elements. Others, like Bean (1983), have suggested that the potential ambiguity, resulted from the loss of subject versus object inflection on nouns, but not pronouns, was avoided by allowing the verb to intervene. Probably both factors worked together to contribute to the word order change (Hogg, 2002, p. 276).

Cambridge History of the English Language explains, "empty subject Par is derived from the locative adverb meaning there", and on some occasions (e.g. [15]) the two may be hard to distinguish. "The locative is always substitutable by a different adverb of place, but the empty par is not". Existential par has "the property of not having full pronominal functions", i.e., it does not "substitute for a noun phrase", and therefore has "none of the participant semantics associated with nominative case"; furthermore, it is "not clearly anaphoric or cataphoric". Rather, it appears "to have been syntacticised and to function as an empty subject that fill a position". (Hogg, 2002, p.218-219)

It has been stated that in OE when (an)other argument(s) is/ are present, the syntactic subject can still be left out. However, the use of $(h) i t /$ there becomes more and more frequent towards the end of the period. Maybe the direct and outward reason that a subject becomes more or less obligatory in ME is linked to the fact that the word order became fixed as SVO. In this order the subject takes up the first position. When the subject was a clause, an infinitive or a heavy $\mathrm{NP}$, these would normally be placed at the end of a clause, according to the principle of end-weight and the initial position was filled with a preliminary subject. Consequently, in completely subjectless constructions $(h) i t$ became the rule, so that all constructions (with only a few clearly defined exceptions such as questions etc.) conformed to the fixed order.

As to the case of there, there is something different. Because of the basic anaphoric function of adverb there, there exists a pattern of There-V-S (e.g. $[5,12,16]$ ). Also, in the Chronicle a sequence of events is typically expressed by co-ordinate clauses and no shift of subject. By contrast, events introduced by there with a verb, signal a new episode in the sequence, typically with a new subject. Therefore, there will naturally be a co-existing pattern, There-be-NP (e.g. [15]). As a result, there is evidently a fuzzy area in which judgments about grammaticality of the two patterns are not clear-cut, e.g. [15]. That is, syntactic constructions become ambiguous in specific contexts and speakers may come to favour a new analysis rather than the old one in the course of time. In other words, in such cases speakers evidently no longer stick to established rules or norms, but begin to extend the validity of a rule to new environments. Therefore, constant use of words may be insufficient, and new, more expressive meanings emerge. For reasons of economy, humans tend to avoid synonymous new words so that adverb there is extended to mean abstract space, introducing the following noun.

Historical linguists believe, there are three important mechanisms of the syntactic change, namely analogy, the reanalysis of surface structures and the process of grammaticalization. By analogy, there-be construction comes into being from the reduction of Then-V and PP-V constructions in OE. Analogical change occurs when one form adjusts to resemble another one with which it is related in form or meaning. For example:

in each fortress: there

In each fortress is king: There is king (in each fortress)

(and) then: (and) there

Then is one port in south-of that land: There is one port in south of that land

Here there has the similar reference and function to PP, and similar part of speech and function to then, so if then and PP can occur in the above clauses, it is also true for there to head them. Simultaneously, the verb following there is usually be, since the preposition in PP has indicated the relationship. In addition, Then-V and PP-V constructions are used to introduce a new topic, so the verbs are of the features to indicate the existence or occurrence of something. Once the subject is obligatory in a clause, the above two clauses only can be filled with there but not it. At the same time, Then-V construction has been gradually leveled out. Then there exist two similar there-initial clauses: There is king and There is also my servant [12]. Owing to the obligatory position of the subject, the resulted construction There is (a) king now allows for a different syntactic analysis, since there may be interpreted as the grammatical subject, while in the similar clause There is also my servant, there is adverbial. The predominating unmarked word order SVC leads to the reanalysis of there in There is a king as subject, though the old analysis of there as adverbial is still supported by the communicative need to emphasize and survives into the present. To distinguish or classify the two formally similar forms, in the old analysis, there, the adverbial, is followed by an old NP, which accordingly is definite, while in the reanalysis, there, the subject, mostly plus verb $b e$, is followed by a new NP, which accordingly is indefinite. 
For another, because of the same reason, then loses its signal function and Then-V pattern becomes out-of-date. There has to be employed thereupon to fill the position of subject to fulfill the discourse requirement to introduce a change of reference or topic. Thus there assumes a grammatical function, which leads to its phonological and semantic changes. There in the new construction can not be an adverb, but a noun equivalent and loses its stressed sound, used with be, especially in the contracted form with be, namely, there's. Syntactically, existential there is placed before the verb in declarative clauses and can be used in question tags. The use of these constructions further testifies to the grammaticalization of there. For another, in terms of markedness, the construction was marked at the outset compared with the unmarked word order SVB, usually in the pattern of NP + V + Locative Phrase. When speakers were to begin using this marked form more frequently, the construction, being used most of the time, would become the unmarked form.

\section{CONCLUSION}

As is analyzed above, the exceptions in the there-be construction, which are simply inexplicable in synchronic terms, can only be explained by reference to past states and developments. Unfortunately, historical studies have not provided any cogent argument over it. It is necessary to analyze there-be construction from historical perspective since the focus is on the derivation of there.

In the historical study, it is evident that there-be construction derivates from archaic Then-V pattern and PP-V pattern by analogy when the subject is obligatory in the clause and because of the analogy the following verb mostly is $b e$. It is demonstrated that there-be construction derivates from archaic Then-V pattern and PP-V pattern by analogy when the subject is obligatory in the clause.

\section{REFERENCES}

[1] Saussure, F. de. (1916/1960). Course in General Linguistics. (trans. W. Baskin). London: Peter Owen.

[2] Schendl, H. (2003). Historical Linguistics. Shanghai: Foreign Language Education Press.

[3] Lyons, John. (1967). A Note on Possessive, Existential and Locative Sentences. Foundation of Language, (3): 390-396.

[4] Heine et al. (1991). Grammaticalization: A Conceptual Framework. Chicago: University of Chicago Press.

[5] Thompson, S. A., \& Mulac, A. (1991). A Quantitative Perspective on the Grammaticization of Epistemic Parentheticals in English. In Traugott and Heine, eds., Vol. 2, 313-29.,

[6] Freeborn, D. (2000). From Old English to Standard English. Beijing: Foreign Language Teaching and Research Press.

[7] Hogg. R. M. (2002).The Cambridge History of the English Language (Vol. 1): the Beginning to 1066. Beijing: Peking University Press.

Qun Ren was born in Huai'an, Jiangsu Province, China in 1973. She received her Master's Drgree from Nanjing Normal University, China in 2010.

She is currently a lecturer of Foreign Language Department, Huaiyin Normal University, Huai'an, China. Her research interests include English Linguistics. 